\title{
SEROLOGIC SURVEY OF HUMANS FOR FLAVIVIRUS WEST NILE IN SOUTHERN MORAVIA (CZECH REPUBLIC)
}

\author{
Zdeněk Hubálek', Bohumír Kříž², Jiří Halouzka ${ }^{1}$ \\ ${ }^{1}$ Institute of Vertebrate Biology, Academy of Sciences, Brno, Czech Republic \\ ${ }^{2}$ National Institute of Public Health, Prague, Czech Republic
}

\begin{abstract}
SUMMARY
A serosurvey for West Nile virus (WNV) was carried out in 525 persons, using a plaque-reduction neutralization microtest (PRN $\mu$ T) with Vero cells and Egyptian topotype Eg-101 strain as test virus. The blood sera were collected in four South-Moravian districts (Hodonín 44 persons, Břeclav 102 persons, Znojmo 170 persons, Jihlava 209 persons) of the Czech Republic in the years 1988 and 1989 , and stored at $-20^{\circ} \mathrm{C}$. Antibodies to WNV were detected in only three humans ( $0.6 \%$ seropositivity): one person each in the districts of Hodonín ( $2.3 \%$ persons positive), Breclav ( $1.0 \%$ positive) and Jihlava (0.5\% positive), with the titres of 1:64, 1:32, and 1:32, respectively. All the three sera were negative for antibody to tick-borne encephalitis virus. The results indicate that activity of WNV in southern Moravia was very low before 1990.
\end{abstract}

Key words: West Nile virus, Flavivirus, Moravia, Czech Republic, serosurvey

Address for correspondence: Z. Hubálek, Medical Zoology Laboratory, Institute of Vertebrate Biology ASCR, Klášterni 2, 69142 Valtice, Czech Republic. E-mail: zhubalek@ivb.cz

\section{INTRODUCTION}

The mosquito-borne West Nile virus (WNV, family Flaviviri$d a e$ ) is the aetiologic agent of West Nile fever (WNF). The most serious manifestation of WNV infection is fatal encephalitis and encephalomyelitis in humans and horses, respectively, as well as mortality in certain domestic and wild birds. WNV is transmitted to humans through the bite of an infected mosquito, usually of the genus Culex but sometimes also by other mosquito genera. The virus can occasionally be transmitted from person to person through blood transfusion or organ transplantation. WNV occurs in Africa, Eurasia, Australia (as ‘Kunjin’ virus) and, since 1999, it has also been reported in the Americas.

In the Czech Republic, WNV was isolated from Culex pipiens mosquito in the district of Břeclav, southern Moravia, after the big flood in 1997; specific antibodies against this virus were detected in that year in $2.1 \%$ of local population, and five cases of WNF were recorded (1-3).

The aim of the present study was to evaluate the activity of WNV in southern Moravia in the past - prior to the flood year 1997, using an indirect method of serological survey of archived human sera.

\section{MATERIALS AND METHODS}

\section{Blood Samples}

The serological survey was organized by the National Institute of Public Health, Praha and Regional/District Hygienic
Services. Blood samples were collected by physicians (general practitioners) from at random selected healthy individuals, i.e. from those not suffering from fever or any signs of immunodeficiency (age ranged from 19 and 64 in both sexes approximately at the same proportion), in the years 1988 and 1989. The blood samples were centrifuged in laboratory 3 to 6 hours after collection, and the separated sera were stored at $-20^{\circ} \mathrm{C}$ in the Serum Bank of Centre of Epidemiology and Microbiology, NIPH until use. Every blood sample taken was coded according to region, district, physician and patient. Every person participating in the study has provided his/her written consent.

\section{Cell Cultures}

Vero E6 and SPEV (pig embryo kidney) cells were serially propagated in Leibowitz L-15 medium (Sigma) supplemented with $10 \%$ of foetal calf serum (FCS, Gibco Bio-Cult) and antibiotics.

\section{Viruses}

Two viruses were used for PRNT: 1. WNV Eg-101 Egyptian topotype of WNV, lineage 1, passaged 16 times in suckling mouse brain and homogenized in PBS with $0.4 \%$ of bovine serum albumin fraction V Sigma). 2. Tick-borne encephalitis virus (TBEV) strain Hypr, Central European topotype of TBEV, passaged 10 times in mouse brain, then 55 times in HeLa cells, and once in suckling mouse brain; homogenized in PBS with $0.4 \%$ of bovine serum albumin. 


\section{Neutralization Test}

Plaque-reduction neutralization test (PRNT) was originally proposed by Madrid and Porterfield $(4,5)$, and adopted to a microtechnique (PRN $\mu \mathrm{T})$ on 96-well (flat-bottomed) sterile microplates (Sarstedt) for cell cultures (6). Tested sera were inactivated at $56^{\circ} \mathrm{C}$ for $30 \mathrm{~min}$, and for screening were diluted 1:4 in L-15 medium; $30 \mu \mathrm{l}$ of the serum (in duplicate) was mixed in a microplate well with 30- $\mu 1$ test dose of the virus (containing about 50 PFU of WNV, passaged in suckling mouse brain homogenized in PBS with $0.4 \%$ of bovine serum albumin fraction $\mathrm{V}$, and centrifuged) in L-15 supplemented with $3 \%$ of inactivated FCS, and incubated at $37^{\circ} \mathrm{C}$ for $60 \mathrm{~min}$. Vero cell suspension (in L-15 with $3 \% \mathrm{FCS}$ ) was then added to each test well ( $60 \mu \mathrm{l}$ with 20,000 to 30,000 cells per well), and after an incubation at $37^{\circ} \mathrm{C}$ for $4 \mathrm{~h}, 120 \mu 1$ of carboxymethylcellulose sodium salt overlay $(1.5 \% \mathrm{CMC}$ of medium viscosity BDH in PBS mixed with the same volume of L-15 with 3\% of inactivated FCS) was added in each well. Controls included the virus test dose and its titration, immune WNV reference serum; control negative serum; and cells without virus. The microplates, sealed in small polyethylene bags, were incubated at $37^{\circ} \mathrm{C}$ for 5 days and the cultures then stained with $0.1 \%$ acidic solution of naphthalene black (Fluka). Sera reactive with virus, revealing $80 \%$ or greater reduction in the number of plaques at the 1:4 dilution at screening (corresponding to the 1:8 final dilution of the serum - after mixing with the virus test dose), were titrated in duplicate by twofold dilutions, and those dilutions corresponding to $80 \%$ reduction of plaque numbers were regarded as the antibody titres $\left(\mathrm{PRN} \mu \mathrm{T}_{80}\right)$. Reciprocal titres $\geq 16$ were considered positive. The foetal calf serum used in PRN $\mu \mathrm{T}$ was tested for antibodies against WNV in a separate assay, with negative response.

The positive sera were also tested analogically in PRN $\mu \mathrm{T}$ against TBEV using SPEV (pig embryo kidney) cells, in order to check for cross reactions with this related Flavivirus occurring in Central Europe.

\section{RESULTS}

Only three of $525(0.6 \%)$ examined persons reacted with WNV at the titre 1:16 or higher (Table 1): 1/44 (2.3\%) persons (no. positive/no. examined) from the district of Hodonín, 1/102 $(1.0 \%)$ from the Břeclav district, $1 / 209(0.5 \%)$ from the Jihlava district, but none of 170 persons tested from the Znojmo district. All three WNV-seroreacting persons were also examined in

Table 1. Subjects with specific antibodies against West Nile virus

\begin{tabular}{|l|c|c|c|c|c|}
\hline $\begin{array}{l}\text { Code } \\
\text { number }\end{array}$ & $\begin{array}{c}\text { Age } \\
\text { (years) }\end{array}$ & Sex & $\begin{array}{c}\text { Date of } \\
\text { collec- } \\
\text { tion }\end{array}$ & District & $\begin{array}{c}\text { PRN } \mu T_{80} \\
\text { titre }^{*}\end{array}$ \\
\hline 3220 & 46 & M & Nov. 1988 & Hodonín & $1: 64$ \\
\hline 3469 & 53 & M & May 1989 & Jihlava & $1: 32$ \\
\hline 3720 & 55 & F & $\begin{array}{c}\text { March } \\
\text { 1988 }\end{array}$ & Breclav & $1: 32$ \\
\hline
\end{tabular}

* the serum dilution corresponding to $80 \%$ reduction of plaque numbers was regarded as the antibody titre
$\mathrm{PRN} \mu \mathrm{T}_{80}$ with TBEV, and none reacted with the latter virus at titres 1:16 or higher.

\section{DISCUSSION}

The plaque-reduction neutralization test is regarded as the "gold standard' in Flavivirus serology and used for verification of other serological tests (such as ELISA, hemagglutination-inhibition test - HIT) because it is generally more specific and discriminatory. However, it is well known that flaviviruses present a high degree of serological cross-reactivity, even in the neutralization test (5, $7-10$ ). Often several antigenically closely related flaviviruses of the same antigenic group co-occur in one area, e.g., in Central Europe TBEV together with WNV. It is therefore sometimes very difficult to decide which particular virus was responsible for the antibody production.

In this study, we used neutralization with the standard topotype Egyptian strain Eg-101 of WNV and with carefully stored and thermally inactivated serum samples devoid of heparin, citrate, EDTA or any stabilizing substances like merthiolate. We estimated the results conservatively, as the $80 \%$ reduction in the number of plaques as an antibody titre cut-off point.

Evidence of the WNV presence in southern Moravia has been based on the virus isolation, five human cases of WNF in 1997, and confirmed by the presence of antibodies in human population that year (1-3). WNV was also isolated previously in neighbouring West Slovakia (11). It was shown later that the WNV strain isolated in South Moravia presents a new, third genomic lineage of the WNV, called 'Rabensburg' (12).

In Belarus areas where WNV strains were isolated from mosquitoes, a bird, and a febrile human patient, the virus antibodies prevailed in $1.7 \%$ of the human population (13). In a similar situation, antibodies neutralizing WNV were detected in $2.1 \%$ of 619 hospitalized patients or subjects seeking outpatient clinics in southern Moravia in 1997 (3).

\section{CONCLUSIONS}

In general, data of the present study indicate indirectly a very limited, if any, WNV activity in southern Moravia prior to 1990 , when only $0.6 \%$ of persons were seropositive against WNV. Moreover, it could not be excluded that these seropositive persons acquired the WNV infection elsewhere than in southern Moravia; their anamnestic data on travelling abroad could not be ascertained.

\section{Acknowledgements}

This study was partly funded by the Internal Grant Agency of Ministry of Health (IGA MZ) reg.no.3482-2, OK08, Grant Agency of the Academy of Sciences of the Czech Republic (IAA 600930611), and the EU grants cCASHc and GOCE-2003-010284 (http://www.eden-fp6project.net); it is catalogued by the EDEN Steering Committee as EDEN0242.

\section{REFERENCES}

1. Hubálek Z, Halouzka J, Juricová Z, Sebesta O. First isolation of mosquito-borne West Nile virus in the Czech Republic. Acta Virol. 1998 Apr;42(2):119-20. 
2. Hubálek Z, Halouzka J, Juricová Z. West Nile fever in Czechland. Emerg Infect Dis. 1999 Jul-Aug;5(4):594-5.

3. Hubálek Z, Savage HM, Halouzka J, Juricová Z, Sanogo YO, Lusk S. West Nile virus investigations in South Moravia, Czechland. Viral Immunol. 2000;13(4):427-33.

4. De Madrid AT, Porterfield JS. A simple micro-culture method for the study of group B arboviruses. Bull World Health Organ. 1969;40(1):113-21.

5. De Madrid AT, Porterfield JS. The flaviviruses (group B arboviruses): a cross-neutralization study. J Gen Virol. 1974 Apr;23(1):91-6.

6. Hubálek Z, Chanas AC, Johnson BK, Simpson DI. Cross-neutralization study of seven California group (Bunyaviridae) strains in homoiothermous (PS) and poikilothermous (XTC-2) vertebrate cells. J Gen Virol. 1979 Feb;42(2):357-62.

7. Theiler M, Downs WG. The arthropod-borne viruses of vertebrates. New Haven and London: Yale University Press; 1973.

8. Calisher CH, Karabatsos N, Dalrymple JM, Shope RE, Porterfield JS, Westaway EG, et al. Antigenic relationships between flaviviruses as determined by cross-neutralization tests with polyclonal antisera. J Gen Virol. 1989 Jan; 70 (Pt 1):37-43.
9. Weingartl HM, Drebot MA, Hubálek Z, Halouzka J, Andonova M, Dibernardo A, et al. Comparison of assays for the detection of West Nile virus antibodies in chicken serum. Can J Vet Res. 2003 May;67(2):128-32.

10. Niedrig M, Sonnenberg K, Steinhagen K, Paweska JT. Comparison of ELISA and immunoassays for measurement of IgG and IgM antibody to West Nile virus in human sera against virus neutralisation. J Virol Methods. 2007 Jan;139(1):103-5.

11. Labuda M, Kožuch $\mathrm{O}$, Grešíková M. Isolation of West Nile virus from Aedes cantans mosquitoes in West Slovakia. Acta Virol. 1974 Sep;18(5):429-33.

12. Bakonyi T, Hubálek Z, Rudolf I, Nowotny N. Novel flavivirus or new lineage of West Nile virus, central Europe. Emerg Infect Dis. 2005 Feb;11(2):225-31.

13. Samoilova TI, Votiakov VI, Titov LP. Virologic and serologic investigations of West Nile virus circulation in Belarus. Cent Eur J Public Health. 2003 Jun;11(2):55-62.

Received August 10, 2010 Accepted in revised form June 2, 2011 